\title{
Amerikai Táplálkozási Ajánlás 2015-2020 - rövid ismertetés
}

Dietary Guidelines for Americans 2015-2020 - short summary

\author{
Szerzők: Fekete Krisztina $₫$, Henter Izabella \\ Nemzeti Egészségfejlesztési Intézet
}

Beküldve: 2016.06.20.

Kulcsszavak: élelmiszer-alapú javaslat, Szocio-Ökológiai Modell, OKOSTÁNYÉR ${ }^{\circledR}$

Keywords: food-based proposal, Socio-Ecological Model, SMART PLATE ${ }^{\circledR}$

Az Egyesület Államok tavalyi évben kiadott, 2020-ig érvényes Táplálkozási Ajánlás (Dietary Guidelines for Americans 2015-2020), az Étrendi Irányelvek Tanácsadó Testület (Dietary Guidelines Advisory Committee, DGAC) jelentése, amely az USA kormánya számára foglalja össze az egészséges táplálkozással, a betegségek megelőzésével kapcsolatos legújabb ajánlásokat, amelyeket az Amerikai Egyesült Államok Mezőgazdasági- és Egészségügyi Minisztériuma is elismer. ${ }^{1}$

Az Amerikai Táplálkozási Ajánlást 1980 óta ötévenként felülvizsgálják. A szakmai grémium, a legújabb kutatási eredmények, evidenciák, tudományos bizonyítékok figyelembe vételével a dokumentációt folyamatosan frissíti, bővíti, a megvalósításhoz javaslatokat ad lakossági és kormányzati szinten egyaránt. A legújabb, 2015-ben megjelent USA táplálkozási ajánlás 570 oldala 18 hónap alatt készült el, amely a bevezetőn, a köszönetnyilvánításon, és az összefoglalón túl (melyek fő üzenetei az anyagban többször ismétlődnek), 3 fejezetet és 14 igen részletes mellékletet tartalmaz.

A jelenlegi szakmai ajánlás elkészítését többek közt az is indokolta, hogy az amerikai felnőttek felének (117 millió ember) van megelőzhető/elkerülhető krónikus betegsége, pl. elhízás, diabétesz, amely a jelentős egészségügyi kockázat mellett igen nagy gazdasági terhet is ró az országra. 2008-ban, az elhízáshoz kapcsolódó orvosi költségeket 147 milliárd \$-ra becsülték az USA-ban, míg 2012-ben a diagnosztizált diabéteszes betegek ellátása 245 milliárd \$-t igényelt.
A 2015-2020 között érvényes Amerikai Táplálkozási Ajánlásról általánosságban elmondható, hogy segítséget nyújt az egészséges táplálkozás/étrend választásához és a táplálkozással összefüggő krónikus megbetegedések megelőzéséhez. Az összeállított szakmai anyag egyik fő újdonsága, hogy szakított az előző kiadások tápanyag-fogyasztási célmeghatározásával, amely nehezebben értelmezhető és kivitelezhető üzeneteket hordozott, helyette közérthetőbb, élelmiszer, élelmiszercsoport alapú javaslatokat tartalmaz, amelyeket gyakorlatias tanácsokkal, részletes és praktikus táblázatokkal egészítettek ki a szerzők. Ez utóbbi táblázatok 13 életkori kategóriában, vagy 12 csoportban - 1000-3200 kcal közötti napi energiaigény szerinti bontásban - adnak tájékoztatást az élelmiszer- illetve bizonyos vitamin- és ásványi-anyag szükségletről. Emellett megjelenik az élelmiszerbiztonság témája is a kézmosástól a megfelelő élelmiszertárolásig. A konkrét élelmiszeralapú mennyiségi és minőségi javaslatokat két étkezési formára - mediterrán és lakto-ovo vegetáriánus - is kidolgozták a szakemberek. [1. ábra]

A megfogalmazott ajánlások adják az alapját a speciális táplálkozási igényű célcsoportok étkezési javaslatainak is - csecsemők, kisdedek, gyermekek (30 millió gyermek étkeztetése/nap), idősek, várandós nők.

Nincsenek tiltott ételek, inkább a "kis mértékben” és „túlzott mértékben”, valamint „népegészségügyi kockázatot rejtő" kategóriákba kerülnek az egészségre gyakorolt hatásuk alapján az élelmiszerek, 
1. ábra: Mediterrán stílusú étkezésben, a különböző élelmiszercsoportok ajánlott mennyisége, eltérő kalóriaszükségletben (részlet)

\begin{tabular}{|c|c|c|c|c|c|c|c|}
\hline Calorie Level of Patterna & 1,000 & 1,200 & 1,400 & 1,600 & 1,800 & 2,000 & 2,200 \\
\hline Food Group & \multicolumn{7}{|c|}{$\begin{array}{l}\text { Daily Amount }{ }^{\mathrm{c}} \text { of Food From Each Group (vegetable and protein foods subgroup } \\
\text { amounts are per week) }\end{array}$} \\
\hline Vegetables & $1 \mathrm{c}$-eq & $11 / 2 \mathrm{c}$-eq & $11 / 2 \mathrm{c}-\mathrm{eq}$ & $2 \mathrm{c}-\mathrm{eq}$ & $21 / 2$ c-eq & $21 / 2 c-e q$ & $3 c$-eq \\
\hline Dark-green vegetables (c-eq/wk) & $1 / 2$ & 1 & 1 & $11 / 2$ & $11 / 2$ & $11 / 2$ & 2 \\
\hline $\begin{array}{l}\text { Red and orange vegetables (c- } \\
\text { eq/wk) }\end{array}$ & $21 / 2$ & 3 & 3 & 4 & $51 / 2$ & $51 / 2$ & 6 \\
\hline $\begin{array}{l}\text { Legumes (beans and peas) (c- } \\
\text { eq/wk) }\end{array}$ & $1 / 2$ & $1 / 2$ & $1 / 2$ & 1 & $11 / 2$ & $11 / 2$ & 2 \\
\hline Starchy vegetables (c-eq/wk) & 2 & $31 / 2$ & $31 / 2$ & 4 & 5 & 5 & 6 \\
\hline Other vegetables (c-eq/wk) & $11 / 2$ & $21 / 2$ & $21 / 2$ & $31 / 2$ & 4 & 4 & 5 \\
\hline Fruits & $1 \mathrm{c}-\mathrm{eq}$ & $1 \mathrm{c}-\mathrm{eq}$ & $11 / 2 \mathrm{c}-\mathrm{eq}$ & 2 c-eq & 2 c-eq & $21 / 2$ c-eq & $21 / 2$ c-eq \\
\hline
\end{tabular}

Forrás: Dietary Guidelines for Americans 2015-2020

illetve egyes összetevők, pl. só, cukor. A táplálkozási ajánlás fő üzenete, hogy az egészséges étkezési szokások nem merev előírások, inkább adaptálható keretek. A különböző élelmiszercsoportok rugalmas kombinációjával válik valóra a hétköznapok szintjén az egyéni igények, preferenciák és kulturális hagyományok figyelembevételével az egészséges táplálkozás, amely illeszkedik a költségvetéshez/büdzséhez. Az Amerikai Táplálkozási Ajánlás 5 átfogó irányelvet is megfogalmaz, melyek képi „magyarázatokkal" is kiegészülnek [2. ábra]:

2. ábra: Amerikai Táplálkozási Ajánlás 2015-2020 áttekintése (részlet)
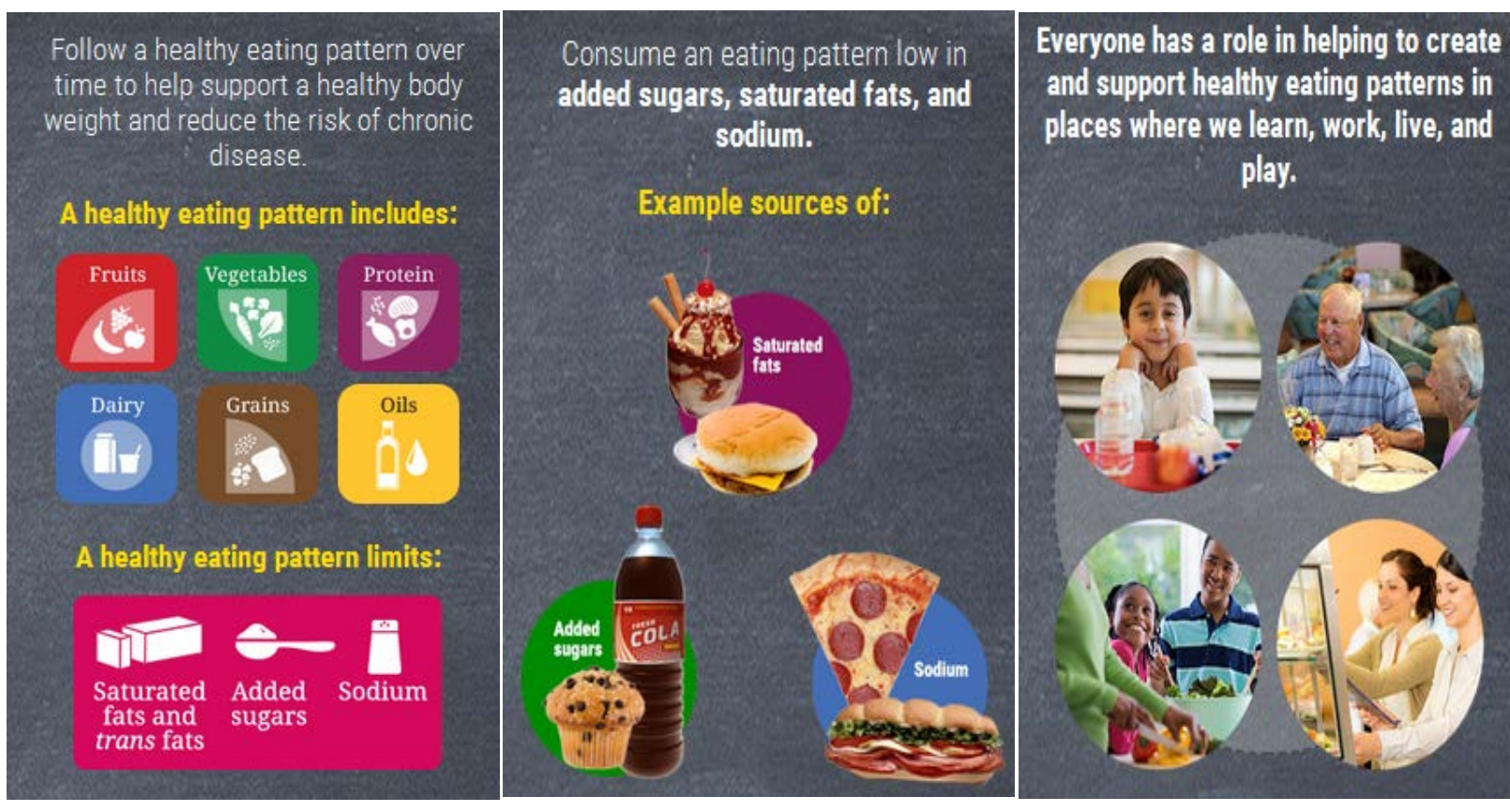

Forrás: Dietary Guidelines for Americans 2015-2020 
Az 5 átfogó irányelv:

- Kövesse az egészséges étkezési szokásokat egész életen át. Minden élelmiszer- és italválasztás számít. Kövessen egészséges étkezési szokásokat megfelelő energia-bevitellel, az egészséges testtömeg elérése/megtartása végett. Megfelelő táplálékokat fogyasszon, így csökkentve a krónikus betegségek kialakulásának kockázatát.

- Fókuszáljon az élelmiszercsoportokra, azok tápanyagtartalmára, mennyiségére, az adag nagyságára. A kalóriahatárokon belül válogasson a tápanyagokban gazdag élelmiszerek közül, mindegyik élelmiszercsoportból az ajánlott mennyiség szerint.

- Korlátozza a kalóriát a hozzáadott cukorból és a telített zsírokból, csökkentse a só/nátrium-bevitelt. Fogyasszon kevesebb ételt és több folyadékot.

- Törekedjen az egészségesebb élelmiszer és italválasztásra. Keressen tápanyagban gazdag élelmiszereket és italokat minden élelmiszercsoportból a kevésbé egészségesebb helyett. Vegye figyelembe a kulturális és a személyes preferenciákat, hogy a változás elérését és fenntartását megkönnyítse.

- Támogasson minden egészséges étkezési szokást! Mindenkinek van szerepe az egészséges táplálkozási szokások kialakításában és támogatásában országszerte több színtéren, a lakóhelytől kezdve, az iskolán és a munkahelyen át, egészen a közösségekig.

Az ajánlás részletesen kitér a fogyasztásra javasolt élelmiszercsoportok fajtáira és minőségére, az egészséges étrend összetételére, tartalmára:

- többféle zöldség minden alcsoportból - sötétzöld, piros és narancsszínűek, hüvelyesek (bab és borsó),

- gyümölcsök, kifejezetten a teljes gyümölcsök,

- gabonafélék (legalább a fele arányban teljes kiőrlésű gabona),

- zsírmentes vagy kis zsírtartalmú tejtermékek,

- különböző fehérjetartalmú élelmiszerek, beleértve a tengeri halakat, sovány húsokat és baromfit, tojást, hüvelyeseket (bab, borsó), dióféléket, magvakat, szója termékeket,

- olajok.
Ezen élelmiszercsoportok mennyiségi bevitele a felmérések alapján jelenleg még nagymértékben eltér - kevesebb - a javasolttól. [3. ábra] Az Amerikai Táplálkozási Ajánlás kitér a korlátozandó ételek, italok, összetevők - hozzáadott cukor, telített zsír, só, alkohol, koleszterin és koffein - körére is. Az energiaegyensúly témáját és a fizikai aktivitás fontosságát is megemlíti az anyag, egyik melléklete a Physical Activity Guidelines for Americans.

A korlátozandó/kerülendő összetevők közül a cukor, a sóbevitel és a telített zsírbevitel forrásait is elemzi a szakmai irányelv, ezzel is segítve a megfelelő élelmiszerválasztást. [4. ábra, 6. ábra, 8. ábra] Érdekességként beillesztettük a hazai OTÁP 2014 évi (Országos Táplálkozás és Tápláltsági Állapot Vizsgálat) eredményeit, amelyek az Országos Gyógyszerészeti és Élelmezés-egészségügyi Intézet (OGYÉl) honlapján elérhetők. [5. ábra, 7. ábra, 9. ábra] ${ }^{2} \mathrm{~A}$ sót, cukrot, telített zsírt tartalmazó élelmiszercsoportok fogyasztása esetében, függetlenül az adatfelvétel, az elemzés módjától az amerikai és hazai adatok alapján hasonló eredmények születtek.

3. ábra: Az egészséges táplálkozás ajánlásához képest, hogyan alakul a különböző élelmiszercsoportok valós bevitele

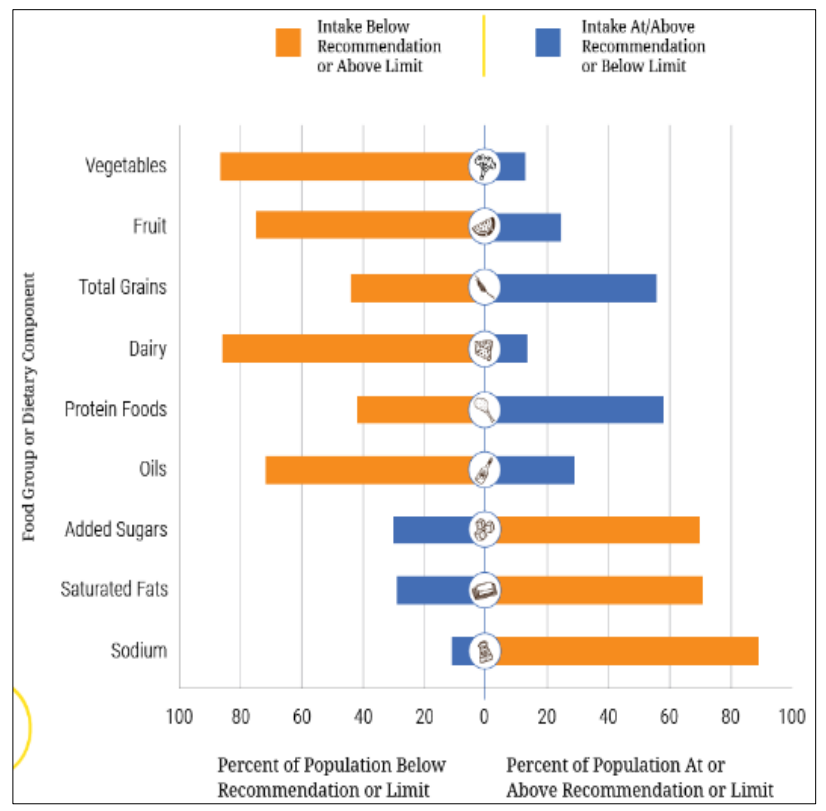

Forrás: Dietary Guidelines for Americans 2015-2020 
4. ábra: Az USA-ban, a 2 évesnél idősebbek körében fogyasztott, hozzáadott cukrot tartalmazó élelmiszercsoportok forrásai

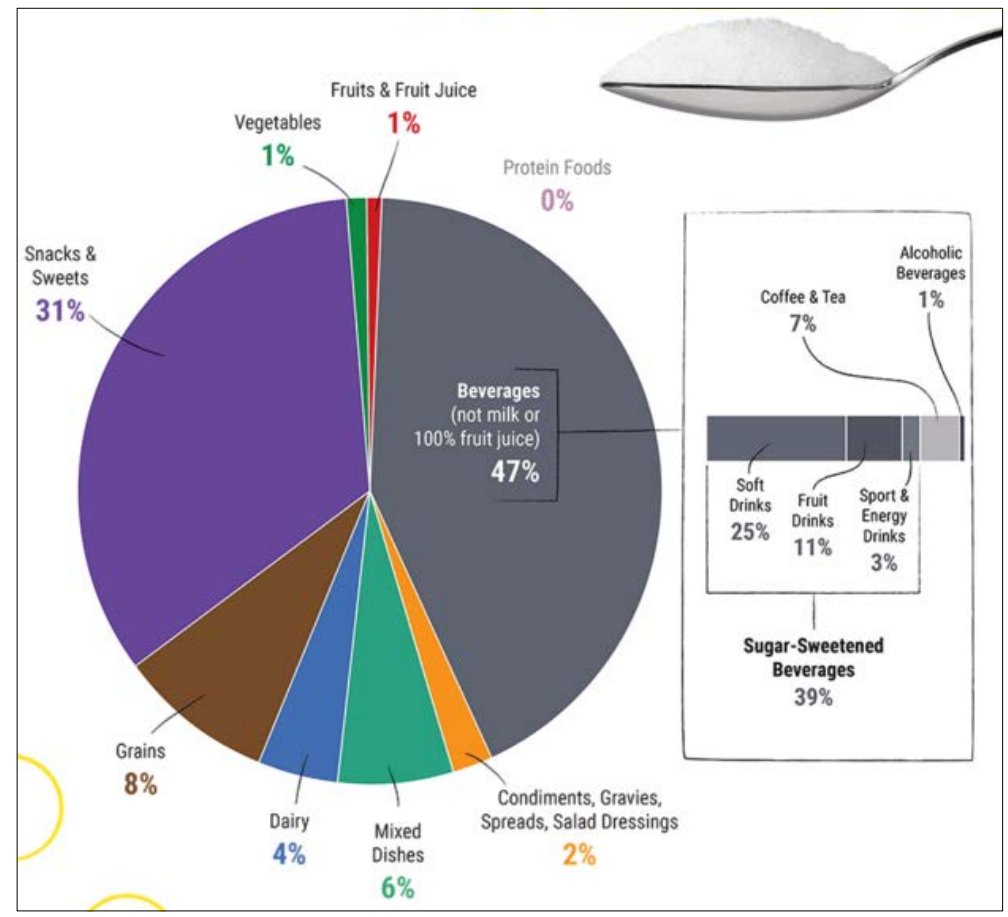

Forrás: Dietary Guidelines for Americans 2015-2020

5. ábra: A feldolgozott élelmiszerekből származó napi átlagos hozzáadott cukorbevitel felnőtteknél

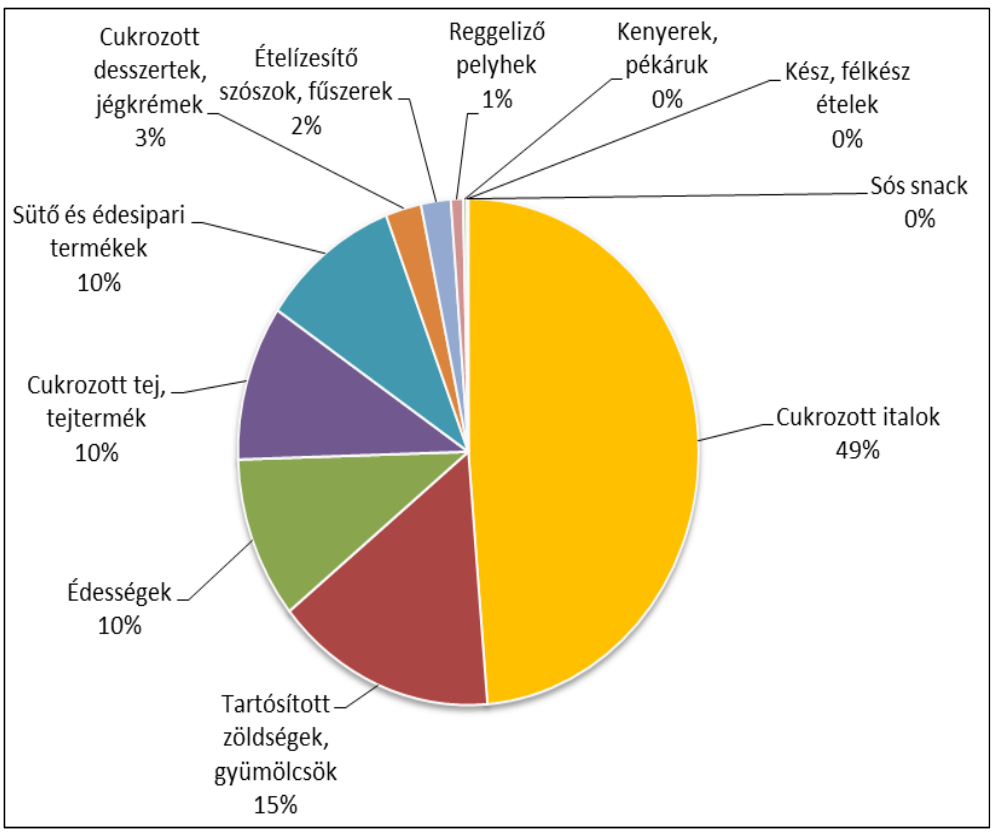

Forrás: OTÁP 2014 
6. ábra: Az USA-ban, a 2 évesnél idősebbek körében fogyasztott, telített zsírt tartalmazó élelmiszercsoportok forrásai

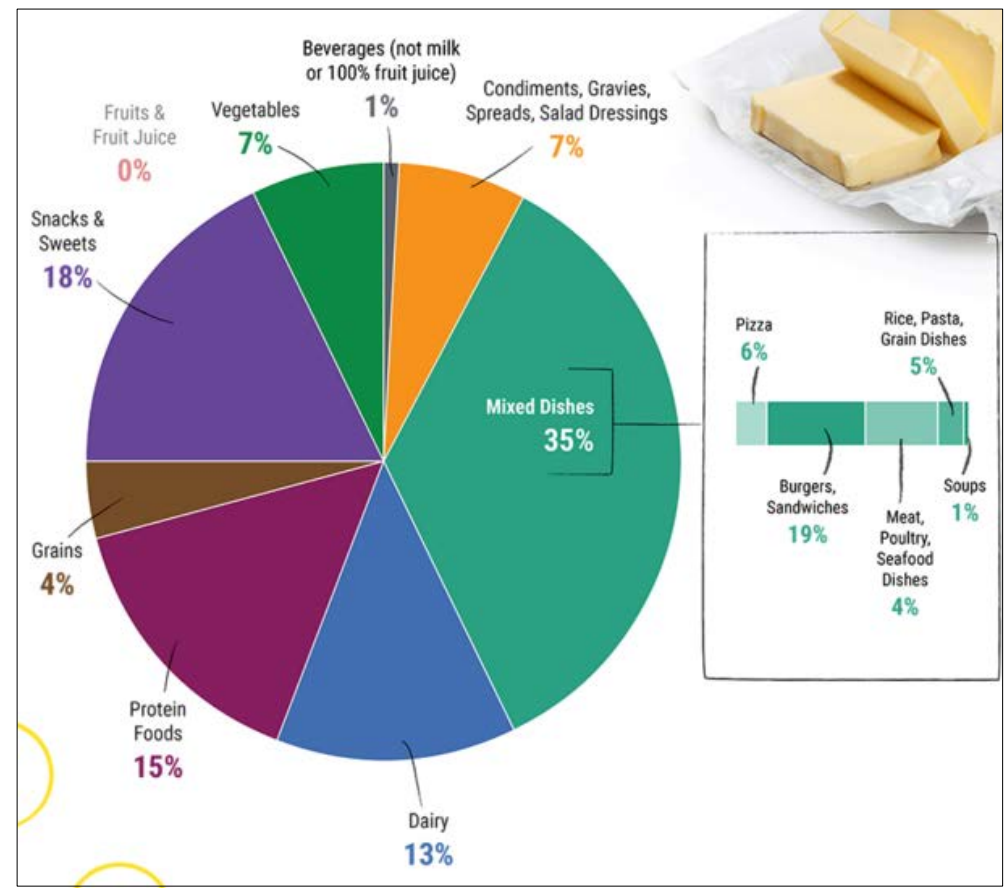

Forrás: Dietary Guidelines for Americans 2015-2020

Férfiak

Nők
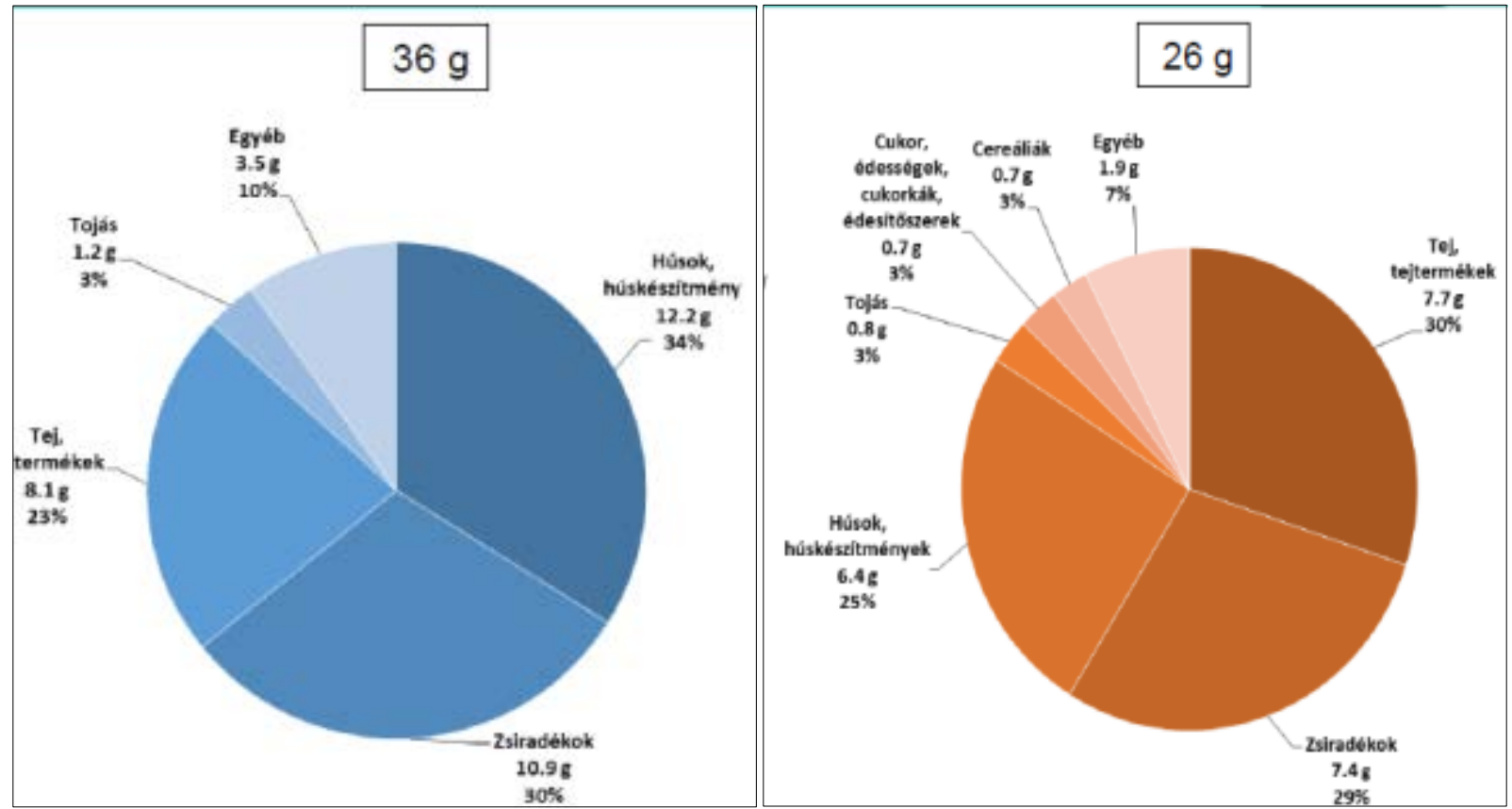

Forrás: OTÁP 2014 
8. ábra: Az USA-ban, a 2 évesnél idősebbek körében fogyasztott, nátriumot tartalmazó élelmiszercsoportok forrásai

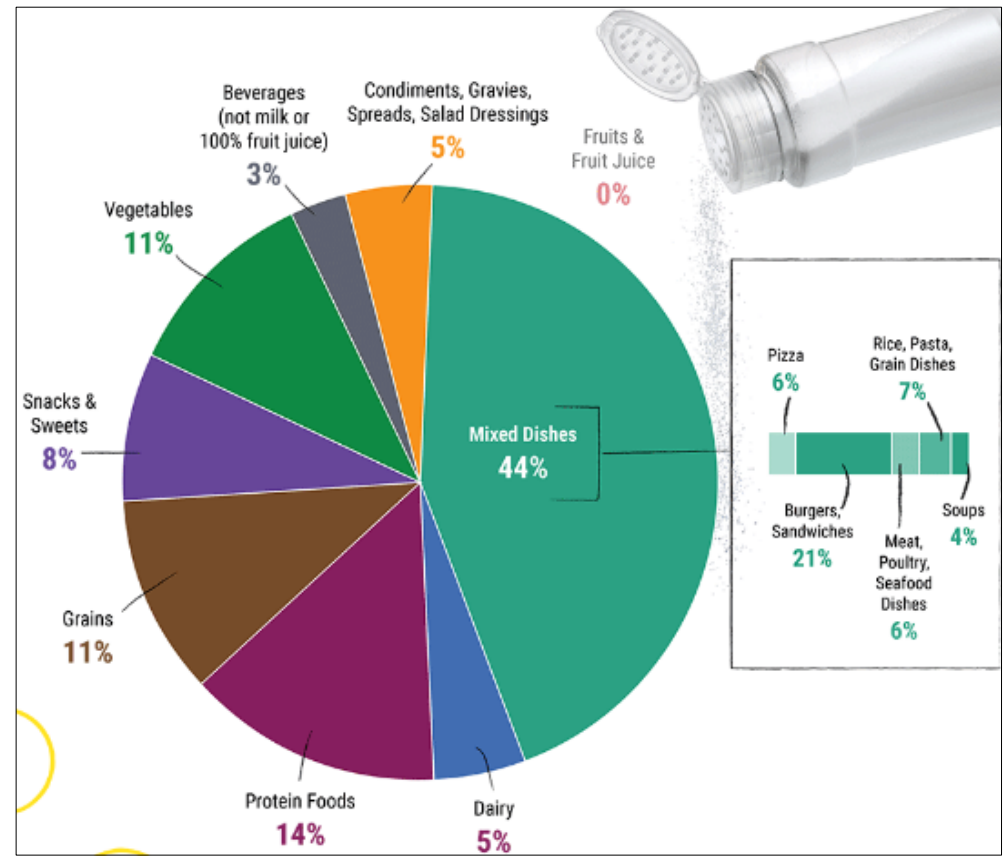

Forrás: Dietary Guidelines for Americans 2015-2020

9. ábra: Felnőttek feldolgozott élelmiszerekből származó napi átlagos sóbevitele

Férfiak

Nők
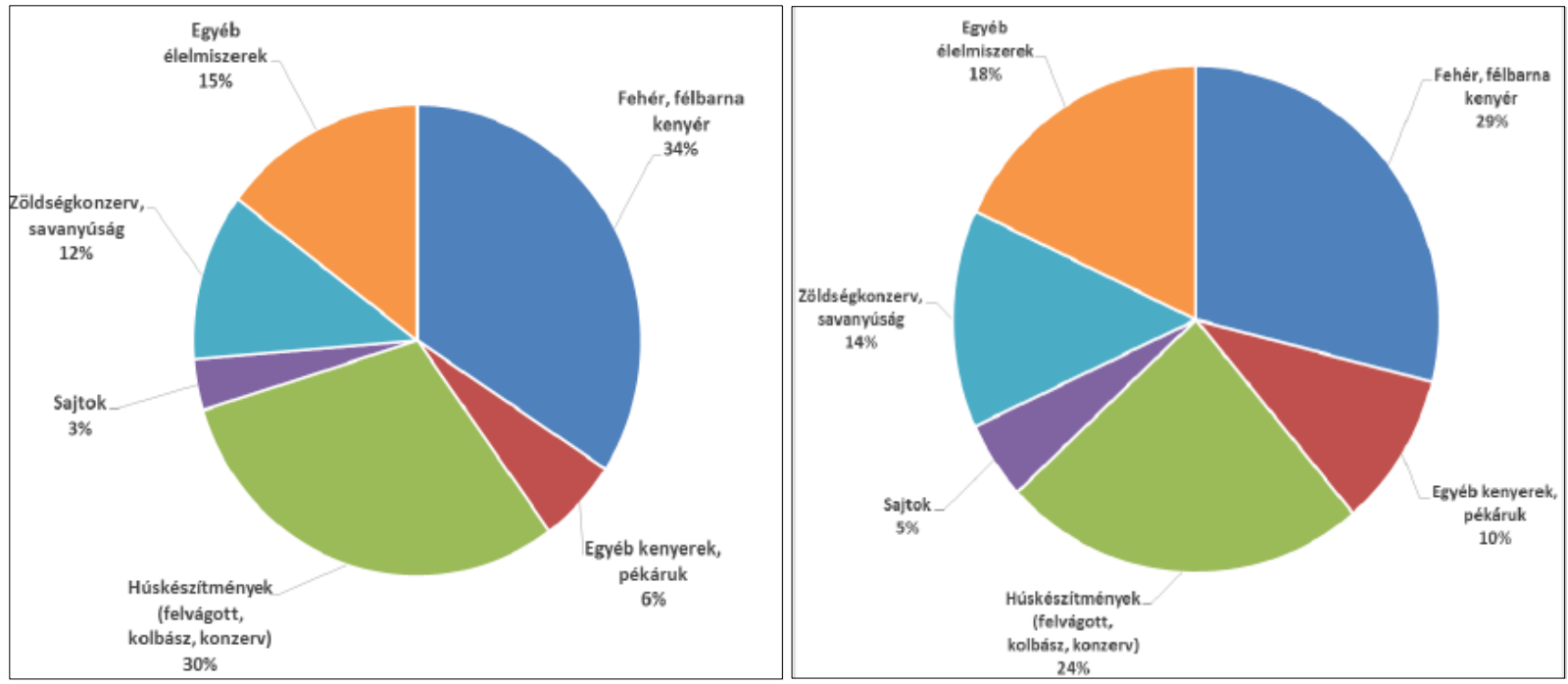

Forrás: OTÁP 2014 
Az élelmiszer-alapú javaslatok mellett a táplálkozási ajánlás egy teljes fejezetet szán arra, hogy sorba vegye a beavatkozások szintjeit. Megfogalmazza, hogy olyan kollektív/közös, több szintű beavatkozásokra van szükség, amelyekben az egészséges életmód választása otthon, az iskolában, a munkahelyen és a közösségekben könnyű, hozzáférhető, megfizethető és irányadó. Mindenkinek szerepe van abban, hogy az egyének változtassanak a mindennapi étkezésükben és fizikai aktivitásukban, a táplálkozási ajánlással összhangban. Ehhez a Szocio-Ökológiai Modellt használták az ajánlás összeállítói, amely különböző szinteken hatékony a táplálkozással és fizikai aktivitással kapcsolatos viselkedés fejlesztésében, figyelembe véve a környezetvédelem szempontjait is. [10. ábra]

E mellett áttekinti az anyag, mi korlátozhatja az egyén vagy a család egészséges táplálkozással kapcsolatos választásait, amelyekre megoldási javaslattal is él.

- Probléma/nehézség: hozzáférés az élelmiszerekhez, pl.: lakókörnyezet és bolt távolsága, száma; egyéni és helyi erőforrások - jövedelem, közösségi közlekedés, társadalmi-gazdasági státusz, földrajzi helyzet, fogyatékosság

- megoldási javaslatok:

- élelmiszerboltok ösztönzése - növeljék az egészséges étkezést támogató élelmiszerek elérhetőségét

- termelői piacok, mobil piacok, élelmiszer bankok, közösségi kertek kialakítása

- Probléma/nehézség: háztartási szinten élelmiszer-elérhetőség/hozzáférés; élelmiszer beszerzéssel és egészséges választással kapcsolatos képesség; biztonságos élelmiszerhez való hozzáférés korlátozott vagy bizonytalan (utóbbi: USA 48 millió embere)

- megoldási javaslatok:

- ágazati hálózatok kialakítása, együttmúködések rászorulók elérése végett - könynyebb élelmiszerválasztás

- Probléma/nehézség: az anyaország lakosai és a bevándorlók közötti kulturális különbségek - attitűd, értékek, szokások (táplálkozási), hiedelmek és a viselkedés

- megoldási javaslatok
- az egészséges étkezési mintákat rugalmasra tervezték, a különböző kultúrák ételeinek, élelmiszereinek fogyasztását figyelembe veszik.

Egyéb beavatkozások/javaslatok:

- ágazatok közötti, valamint színtereken végrehajtott beavatkozások (otthon, iskola, munkahely, közösség, élelmiszer kiskereskedelem),

- szakemberek és egyének együttműködése,

- partnerségek elősegítése az élelmiszergyártókkal, beszállítókkal és kereskedőkkel, az olyan élelmiszerek hozzáférésének növelése érdekében, amelyek összhangban vannak a táplálkozási ajánlással,

- élelmiszer-termékek fejlesztése és elérhetővé tétele a kiskereskedelemben, amelyek összhangban vannak a táplálkozási ajánlással,

- olyan készségek tanítása, mint kertészkedés, főzés, ételek és étkezések tervezése, élelmiszercímkék olvasása, amelyek segítik az egészséges táplálkozást.

Az Amerikai Táplálkozási Ajánlás tartalma közül kiemelendő, a(z):

- élelmiszercsoport alapú megközelítés,

- gyakorlatias tanácsok,

- praktikus táblázatok,

- részletes, mindent pontosan definiáló meghatározások, leírások,

- rövid, tömör, könnyen értelmezhető üzenetek, - a felelősség kérdése,

- élelmiszerbiztonság/élelmiszerhez való hozzáférés témája,

- az irányelv rendszeres frissítése, bővítése.

Hazánkban 2016 év elején jelent meg a Magyar Dietetikusok Országos Szövetsége (MDOSZ) által öszszeállított, a Magyar Tudományos Akadémia Élelmiszertudományi Tudományos Bizottsága ajánlásával az új magyar táplálkozási ajánlás, az OKOSTÁNYÉR ${ }^{\circledR}$, amely az amerikai ajánláshoz hasonlóan, az egészséges táplálkozás megvalósításához segítségként élelmiszer-alapú javaslatokat fogalmazott meg. [11. ábra] Az OKOSTÁNYÉR ${ }^{\circledR}$ teljes anyaga letölthető az MDOSZ honlapjáról. 3,4 
10. ábra: Szocio-Ökológiai Modell

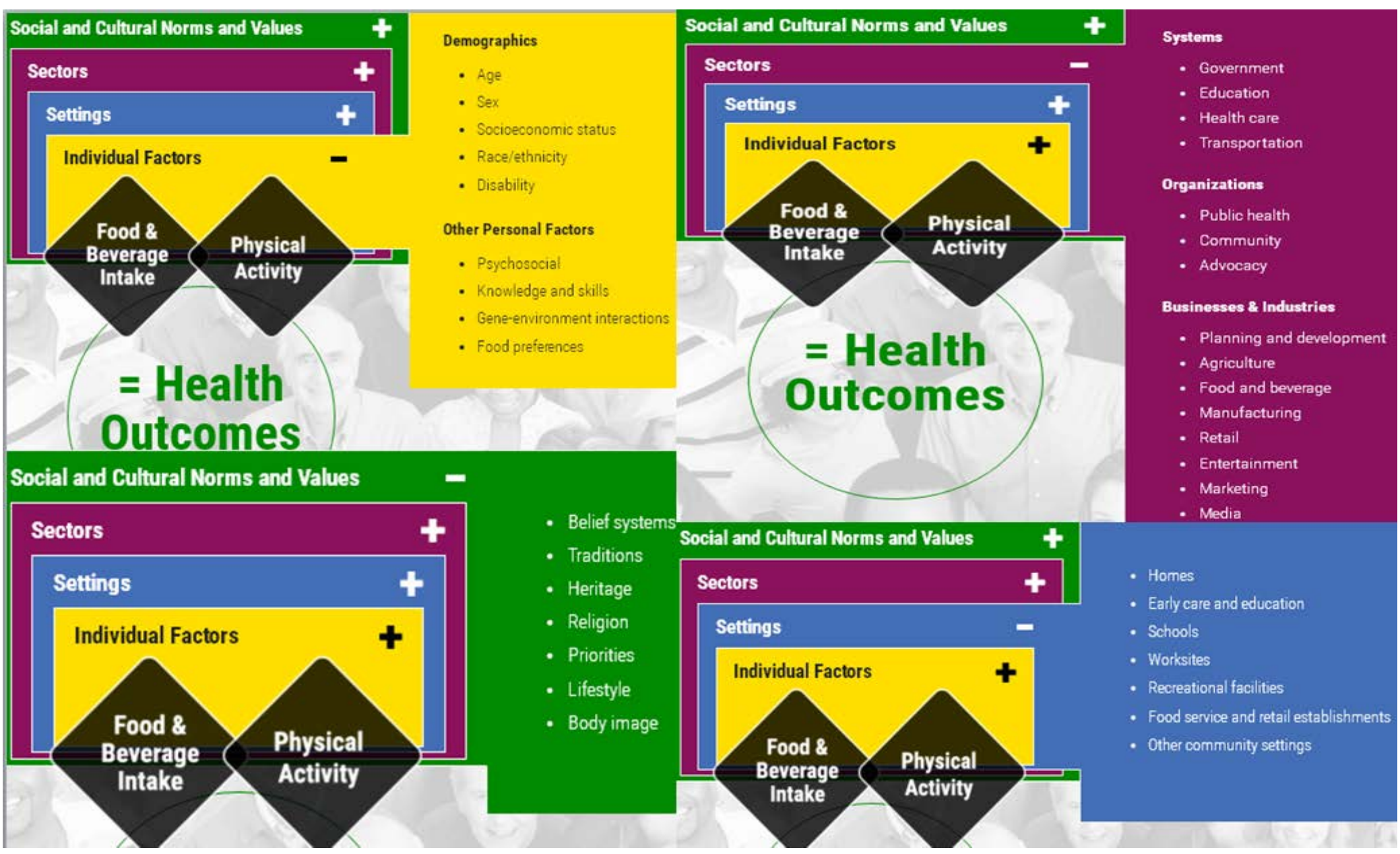

Forrás: Dietary Guidelines for Americans 2015-2020 
11. ábra: OKOSTÁNYÉR ${ }^{\circledR}$ - Új magyar táplálkozási ajánlás (részlet)

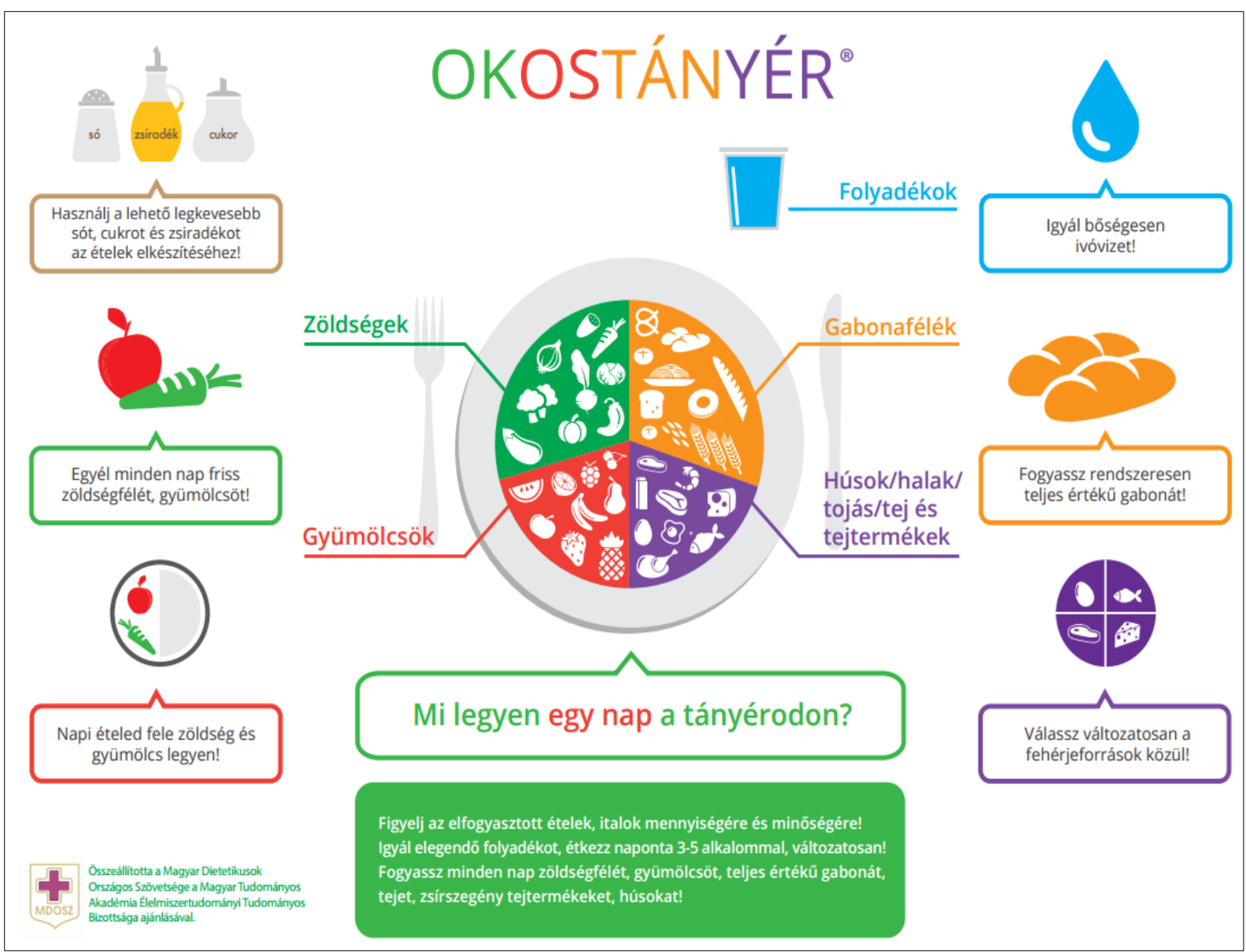

Forrás: MDOSZ - OKOSTÁNYÉR ${ }^{\circledR}$

${ }^{1}$ http://health.gov/dietaryguidelines/2015/guidelines/(Letöltve: 2016.06.23.)

2 https://www.ogyei.gov.hu/otap_2014/ (Letöltve: 2016.06.23.)

${ }^{3}$ http://mdosz.hu/uj-taplalkozasi-ajanlasok-okos-tanyer/ (Letöltve: 2016.06.23.)

${ }^{4}$ http://mdosz.hu/hun/wp-content/uploads/2016/05/Taplalkozasi_Akademia_2016 05_OKOSTANYER_160530.pdf (Letöltve: 2016.06.23.) 